\title{
Removal of Trace Amounts of Copper from Concentrated Hydrochloric Acid Solutions
}

\author{
Metehan Erdoğan ${ }^{1}$, Esra Karakaya ${ }^{2,3}$, Mustafa Serdal Aras ${ }^{3}$, Sedef Çift Karagüil ${ }^{4}$ \\ Merve Kolay Ersoy ${ }^{4}$, Abdullah Öztürk ${ }^{2}$, Ishak Karakaya ${ }^{2}$ \\ ${ }^{1}$ Department of Metallurgical and Materials Engineering, Ankara Yıldırım Beyazıt University; Ayvalı \\ Mahallesi, 150. Sok. \& Takdir Cad. No:5, 06010 Etlik - Keçiören, Ankara, TURKEY \\ ${ }^{2}$ Department of Metallurgical and Materials Engineering, Middle East Technical University; \\ Üniversiteler Mahallesi, Dumlupınar Bulvarı No:1, Çankaya, Ankara, 06800, TURKEY \\ ${ }^{3}$ MEGAP Co. ODTÜ Teknokent Gümüş Blok (A) No:15-A, Çankaya, Ankara, 06800, TURKEY \\ ${ }^{4}$ Borusan Technology Department and R\&D Co.; \\ Büyükhanlı Plaza Defne Sok. No:3, Ataşehir, İstanbul, 34758, TURKEY \\ *E-mail: metehanerdogan@ybu.edu.tr
}

doi: $10.20964 / 2018.11 .75$

Received: 9 July 2018 / Accepted: 3 September 2018 / Published: 1 October 2018

\begin{abstract}
Pickling process is recognized as one of the strongest acid consuming processes in the steel industry. A pickling solution that contains hydrochloric acid $(\mathrm{HCl})$ is used for the metal surface treatment of steel plants. The same acid can be used for a long period of time by means of a regeneration process, in which iron concentration of the acid is decreased to insignificant concentrations. However, regenerated pickling solutions contain copper, especially when scrap is used to produce steel. Furthermore, copper deposits on the metal in the following pickling processes when its concentration exceeds a certain critical value. This study describes an electrochemical treatment process for collecting copper from regenerated pickling solutions of steel plants. Copper concentration, electrolysis time, and current density were selected as the operation variables and $\mathrm{pH}$ and conductivity of the acid together with the amount and morphology of the deposition were considered as the response variables for optimization. Graphite was used as the anode due to its high conductivity and stability and copper or stainless steel was used as the cathode in this study. The results showed that electrochemical treatment process decreased copper concentration to about 80 from $127 \mathrm{ppm}$ using stainless steel cathode under the optimum constant current density of $2.0 \mathrm{~A} / \mathrm{dm}^{2}$ and electrolysis time of 4 hours, without any acid loss, which was verified by $\mathrm{pH}$, conductivity and acidity measurements.
\end{abstract}

Keywords: Copper electrodeposition; Copper recovery; Pickling solution; Current density

\section{FULL TEXT}


(C) 2018 The Authors. Published by ESG (www.electrochemsci.org). This article is an open access article distributed under the terms and conditions of the Creative Commons Attribution license (http://creativecommons.org/licenses/by/4.0/). 